\title{
Uji Aktivitas Antioksidan, Uji Antikolesterol, dan Toksisitas dari Ekstrak Etanol Daun Kemuning (Murraya Paniculata L.Jack)
}

\author{
Yunahara Farida*, Rahmatul Qodriah, Atika Puti Widyana, Zauhara Ifani \\ Fakultas Farmasi Universitas Pancasila, Jakarta \\ *Email : yunahara.faridah@univpancasila.ac.id
}

(Submit 19/12/2021, Revisi 20/12/2021, Diterima 30/12/2021, Terbit 31/12/2021)

\begin{abstract}
Abstrak
Daun kemuning (Murraya paniculata L.Jack) secara empiris banyak digunakan sebagai antibakteri, anti inflamasi, penurun kadar kolesterol darah dan juga sebagai antioksidan. Tujuan penelitian adalah menguji aktivitas antioksidan, antikolesterol secara in vitro dan menguji toksisitas secara BSLT menggunakan ekstrak etanol daun kemuning. Daun kemuning diekstraksi menggunakan etanol 96\% secara maserasi kinetik, selanjutnya ekstrak yang diperoleh dilakukan skrining fitokimia, diuji aktivitas antioksidannya menggunakan metode peredaman radikal bebas DPPH, uji antikolesterol menggunakan metode Liebermann-Burchard dan uji toksisitas menggunakan metode Brine Shrimp Lethality Test. Hasil skrining fitokimia menunjukkan bahwa ekstrak daun kemuning mengandung flavonoid, saponin, tanin, steroid/triterpenoid, minyak atsiri dan kumarin. Hasil uji aktivitas antioksidan ekstrak etanol daun kemuning diperoleh nilai $\mathrm{IC}_{50}$ sebesar $18,56 \mu \mathrm{g} / \mathrm{mL}$, hasil uji aktivitas antikolesterol dengan nilai $I_{50}$ sebesar $593,95 \mu \mathrm{g} / \mathrm{mL}$ dan uji toksisitas dengan nilai $\mathrm{LC}_{50}$ sebesar $149,52 \mu \mathrm{g} / \mathrm{mL}$. Berdasarkan hasil penelitian menunjukkan bahwa daun kemuning mempunyai aktivitas antioksidan yang sangat kuat dan dapat dimanfaatkan sebagai obat herbal.
\end{abstract}

Kata kunci: BSLT, Daun kemuning, DPPH, Liebermann-Burchard.

\section{Pendahuluan}

Pada era sekarang ini, manusia tidak dapat lagi terbebas dari radikal bebas yang masuk ke dalam tubuh. Radikal bebas ini dapat bersumber dari polusi lingkungan, asap rokok, radiasi sinar ultraviolet, alkohol, dan lain-lain. Pembentukan sel radikal bebas yang terus meningkat dalam tubuh dapat mengakibatkan stres oksidatif, yaitu terjadinya ketidakseimbangan antara jumlah antioksidan dan jumlah radikal bebas di dalam tubuh. Stress oksidatif merupakan salah satu faktor utama penyebab timbulnya penyakit kronis dan degeneratif termasuk, penyakit jantung iskemik, penuaan, diabetes mellitus, kanker, penyakit neurodegeneratif dan aterosklerosis. Aterosklerosis yang dapat 
menyebabkan hipertensi, dan penyumbatan pada pembuluh darah otak akan menyebabkan penyakit serebrovaskular seperti stroke (1). Atas dasar itu, sekarang ini semakin banyak penelitian mengenai obat tradisional karena adanya kesadaran masyarakat untuk memperbaiki pola konsumsinya dengan gerakan back to nature.

Bumi Indonesia dikenal sebagai bumi yang sangat kaya akan sumber daya alam. Baik berupa sayur-sayuran ataupun buah-buahan. Banyak tanaman obat yang hidup liar di hutan dan lautan yang belum terjamah tangan manusia. Sebagian memang telah dimanfaatkan dan dibudidayakan dan sebagian lainnya masih diteliti secara mendalam oleh para ilmuwan (2). Salah satu tanaman yang berkhasiat sebagai obat adalah kemuning. Secara empiris kemuning berkhasiat sebagai analgesik, peluruh dahak, peluruh haid, penurun panas, keputihan, mencret, pengurus badan, pencernaan tidak baik, radang ginjal, rematik, stimulant dan depresan jantung. Berdasarkan hasil penelitian yang dilakukan terhadap kadar kolesterol darah marmot jantan (Cavia cobaya) diberikan ekstrak etanol daun kemuning dengan dosis $100 \mathrm{mg} / \mathrm{kg} \mathrm{BB}, 200$ $\mathrm{mg} / \mathrm{kg}$ BB dan $400 \mathrm{mg} / \mathrm{kg}$ BB didapatkan hasil yang menunjukkan bahwa ekstrak etanol daun kemuning memberikan penurunan kadar kolesterol yang tidak berbeda secara nyata dengan pemberian suspensi simvastatin $0,80 \mathrm{mg} / \mathrm{kgBB}$ (3). Peneliti lainnya meneliti tentang ramuan penurun kolesterol darah yang terdiri dari tiga formula dengan perbandingan komposisi yang berbeda, masing-masing penyusun tanaman obat terlihat mampu menurunkan kolesterol darah, adapun tanaman obat tersebut adalah daun jati belanda, akar kelembak, dan daun kemuning. Diberikan formula jamu dalam empat waktu yang berbeda dimana awal bulan rata-rata kadar kolesterol subyek adalah 259,66 mg/dl, lalu pada awal bulan 1 didapatkan rata-rata 235,34 mg/dl, kemudian awal bulan ke 2 rata-rata menurun menjadi 214,17 dan pada akhir bulan ke 3 kadar kolesterol turun menjadi 191,83 mg/dl. Sehingga dapat dikatakan daun kemuning memiliki aktivitas antikolesterol (4).

Sebelumnya telah dilakukan penelitian terhadap potensi antioksidan ekstrak etanol daun kemuning (Murraya paniculata L.) dengan Metode FTC dan DPPH, hasil uji menunjukkan ekstrak etanol daun kemuning dengan metode DPPH memberikan nilai $\mathrm{IC}_{50}$ sebesar $126,17 \mu \mathrm{g} / \mathrm{mL}$. Daun kemuning memiliki kadar fenol dan flavonoid dua kali lebih kecil dari kulit manggis namun nilai $I \mathrm{IC}_{50}$ daun kemuning tujuh kali lebih besar dari kulit manggis (5).

Metode BSLT dilakukan untuk memprediksi toksisitas suatu bahan dan digunakan untuk mendeteksi toksisitas ekstrak tanaman, logam berat dan toksin sianobakteria. Apabila ekstrak tersebut termasuk golongan tidak toksik maka kemungkinan dapat dikembangkan penggunaannya untuk tujuan yang lebih luas, misalnya sebagai makanan suplemen atau bahan baku kosmetika, sedangkan apabila termasuk golongan senyawa toksik maka kemungkinan penggunaannya dapat dikembangkan untuk bahan baku obat.

Berdasarkan penelitian mengenai uji sitotoksik terhadap fraksi $n$-heksan dan methanol dari daun kemuning dengan metode BSLT (Brine Shrimp Lethality Test) terhadap fraksi n-heksana didapat nilai $\mathrm{LC}_{50}$ sebesar $6375 \mu \mathrm{g} / \mathrm{mL}$, fraksi metanol didapat didapat nilai 
$\mathrm{LC}_{50}$ sebesar $707,64 \mu \mathrm{g} / \mathrm{mL}$, senyawa murni hasil isolasi memberikan $\mathrm{LC}_{50}$ sebesar $194,786 \mu \mathrm{g} / \mathrm{mL}$. Artinya senyawa murni hasil isolasi ini tidak memberikan efek toksik terhadap larva Artemia salina Leach (6).

\section{Metode}

\section{Alat}

Timbangan analitik AND HR-120, Maserator (IKA RV10), spektrofotometer UV-Vis (Shimadzu UV 1800), Lampu TL 18 watt, Rotary evaporator (Heidolph)

\section{Bahan}

Daun kemuning (Murraya paniculata (L.) Jack), etanol 96\%, asam sulfat pekat (Mallinckrodt Chemicals, USA), asetat anhidrat (Merck, Germany), dan baku kolesterol (Sigma Aldrich, USA). Pereaksi Mayer, Dragendorff, pereaksi Stiassny, asam klorida, natrium hidroksida, serbuk magnesium, amil alkohol, besi(III) klorida, natrium asetat, DPPH, larva udang Artemia salina Leach, garam laut, vitamin C.

\section{Prosedur}

\section{Pembuatan Ekstrak}

Daun kemuning yang sudah dideterminasi di Pusat penelitian Biologi LIPI, dikeringkan dan dihaluskan menjadi serbuk, selanjutnya di ekstrasi dengan cara maserasi kinetik menggunakan etanol 96\%. Maserat yang diperoleh dipekatkan dengan rotary evaporator.

Skrining Fitokimia. Skrining fitokimia dilakukan terhadap serbuk simplisia ekstrak etanol 96\% menggunakan metode Farnsworth (7) meliputi identifikasi golongan flavonoid, alkaloid, saponin, tanin, kuinon, steroid/triterpenoid, kumarin dan minyak atsiri.

\section{Uji Aktivitas Antioksidan}

Ekstrak kental daun kemuning ditimbang lebih kurang $5 \mathrm{mg}$, dilarutkan dalam metanol pro analisis hingga $5,0 \mathrm{~mL}$ sehingga diperoleh larutan uji dengan konsentrasi 1000 bpj sebagai larutan induk. Dipipet sebanyak 25, 50, 75, 100, dan $125 \mu \mathrm{L}$, dimasukkan ke dalam labu tentukur 5,0 mL, kedalam masing-masing labu tentukur ditambahkan $1,0 \mathrm{~mL}$ larutan DPPH 0,4 mM, ditambahkan metanol pro analisis hingga tanda, dihomogenkan sehingga diperoleh konsentrasi 5,10,15,20, dan 25 bpj. Larutan vit.C sebagai kontrol positif dibuat dengan konsentrasi 1,2,3,4, dan 5 bpj. Selanjutnya diinkubasi pada suhu $37^{\circ} \mathrm{C}$ selama 30 menit. Serapan dibaca 
pada panjang gelombang $515 \mathrm{~nm}$. Dilakukan kontrol negatif (blanko) dengan memipet $1 \mathrm{~mL}$ larutan DPPH 0,4 mM dalam pelarut metanol. Data nilai serapan yang diperoleh dari uji aktivitas antioksidan digunakan untuk menentukan persentase inhibisi dengan rumus:

$$
\text { persen inhibisi (\%) }=\frac{\text { serapan blanko }- \text { serapan uji }}{\text { serapan blanko }} \times 100 \%
$$

Nilai $I_{50}$ adalah konsentrasi antioksidan $(\mu \mathrm{g} / \mathrm{mL})$ yang mampu menghambat aktivitas radikal bebas sebanyak $50 \%$. Nilai $\mathrm{IC}_{50}$ diperoleh dari kurva perpotongan garis antara konsentrasi (sumbu $\mathrm{x}$ ) dengan \% peredaman radikal bebas (sumbu $\mathrm{y}$ ), sehingga diperoleh persamaan $y=a+b x$, dimana $x=$ nilai $I C I C_{50}$ dan $y=50$ (8).

\section{Uji Toksisitas dengan Metode BSLT}

Terhadap ekstrak kental daun kemuning dilakukan uji toksisitas menggunakan metode BSLT (9) dengan menggunakan larva Artemia salina Leach. Mula-mula telur Artemia salina ditetaskan di dalam air laut buatan (38 g garam tanpa iodium dalam $1000 \mathrm{~mL}$ air biasa) di bawah lampu TL 18 watt. Media penetasan telur diberi aerasi udara. Setelah 48 jam larva menetas menjadi nauplii dan siap untuk digunakan. Nauplii sebanyak 10 ekor dimasukkan ke dalam 5 vial yang berisi larutan sampel dalam air laut dengan konsentrasi 20,40,100,200 dan 400 bpj dengan 3 kali ulangan. Semua vial di inkubasi pada suhu kamar selama 24 jam dibawah penerangan lampu TL 18 watt. Pengamatan dilakukan setelah 24 jam dengan melihat jumlah Artemia salina yang mati pada setiap konsentrasi. Perhitungan nilai $\mathrm{LC}_{50}$ dilakukan menggunakan analisis probit. Menurut Meyer, suatu ekstrak dikatakan toksik terhadap Artemia salina Leach apabila nilai $\mathrm{LC}_{50}<1000 \mathrm{bpj}$.

4. Uji Aktivitas Anti Kolesterol

a) Larutan induk kolesterol dibuat dengan konsentrasi 1000 bpj yaitu dengan cara melarutkan $100 \mathrm{mg}$ serbuk kolesterol dalam $100 \mathrm{ml}$ kloroform diaduk hingga larut.

b) Pembuatan Kurva Baku. Dipipet sebanyak 0,25; 0,5; 0,75; 1; dan 1,25 ml dari larutan induk, kemudian ditambahkan kloroform sampai $5,0 \mathrm{~mL}$ sehingga diperoleh konsentrasi 50, 100, 150, 200, dan 250 bpj. Masing-masing larutan tersebut ditambahkan $2,0 \mathrm{~mL}$ asetat anhidrat dan $0,1 \mathrm{~mL}$ asam sulfat kemudian dihomogenkan dengan menggunakan vortex, lapisan luar tabung ditutup. 
menggunakan alumunium voil untuk melindungi dari cahaya dan diukur serapannya pada panjang gelombang maksimumnya $(670 \mathrm{~nm})$. Kemudian dibuat kurva hubungan antara konsentrasi dengan absorbansi

c) Penentuan Aktivitas Kolesterol

Dipipet sebanyak 0,$8 ; 1 ; 1,2 ; 1,4$ dan $1,6 \mathrm{~mL}$ dan di cukupkan sampai $2 \mathrm{~mL}$ sehingga diperoleh konsentrasi 400, 500, 600, 700, dan 800 bpj. Kemudian ditambah $5 \mathrm{~mL}$ kolesterol, lalu di reaksikan dengan $2 \mathrm{~mL}$ asetat anhidrat dan 0,1 $\mathrm{mL}$ asam sulfat pekat. Larutan didiamkan di tempat gelap hingga terbentuk perubahan warna menjadi hijau. Penelitian dilakukan triplo. Selanjutnya dibaca dengan spektrofotometer UV-Vis pada panjang gelombang $670 \mathrm{~nm}$. Sebagai blanko digunakan $5 \mathrm{~mL}$ kloroform ditambah $2 \mathrm{~mL}$ asetat anhidrat dan $0,1 \mathrm{~mL}$ asam sulfat pekat. Sedangkan kontrol negatif yang digunakan berupa $5 \mathrm{ml}$ larutan kolesterol 140 bpj dalam kloroform ditambah $2 \mathrm{~mL}$ asetat anhidrat dan 0,1 $\mathrm{mL}$ asam sulfat pekat (10).

\section{Hasil}

Hasil skrining fitokimia. Hasil skrining fitokimia serbuk dan ekstrak etanol daun kemuning menunjukkan adanya metabolit sekunder flavonoid, saponin, tanin, steroid/triterpenoid, kumarin, minyak atsiri. Hasil skrining fitokimia disajikan pada Tabel 1.

Tabel 1. Hasil skrining fitokimia simplisia dan ekstrak daun kemuning

\begin{tabular}{lcc}
\hline Golongan Senyawa & Simplisia & Ekstrak \\
\hline Flavonoid & - & - \\
Tanin & + & + \\
Saponin & + & + \\
Kuinon & - & - \\
Steroid/Triterpenoid & + & + \\
Kumarin & + & + \\
Minyak Atsiri & + & + \\
\hline Keterangan : (+) : memberikan hasil positif (-): memberikan hasil negatif
\end{tabular}

\section{Hasil Uji antioksidan}

Sifat antioksidan dari suatu senyawa dapat ditentukan dengan menggunakan uji peredaman radikal bebas (DPPH) dengan vitamin $\mathrm{C}$ sebagai kontrol posif. Vitamin $\mathrm{C}$ dipilih sebagai kontrol positif karena vitamin $C$ merupakan antioksidan yang kuat, dan umum digunakan. Aktivitas antioksidan ditentukan dengan nilai $\mathrm{IC}_{50}$ yaitu konsentrasi antioksidan yang mampu menghambat $50 \%$ aktivitas radikal bebas. Uji antioksidan dilakukan karena sifat antioksidan dari suatu senyawa memiliki kaitan dengan berbagai penyakit yang disebabkan oleh stress oksidatif. Hasil uji aktivitas antioksidan pada ekstrak daun kemuning dapat dilihat pada Tabel 2. 
Tabel 2. Hasil Uji Aktivitas Antioksidan Ekstrak Daun Kemuning dan Vit.C

\begin{tabular}{lccc}
\hline Sampel & $\begin{array}{c}\text { Konsentrasi } \\
(\mathbf{b p j})\end{array}$ & $\begin{array}{c}\text { Inhibisi } \\
(\%)\end{array}$ & $\begin{array}{c}\mathbf{I} \mathbf{C}_{\mathbf{5 0}} \\
(\boldsymbol{\mu g} \mathbf{m L})\end{array}$ \\
\hline & 5 & 12,35 & \\
Ekstrak & 10 & 27,93 & \\
daun kemuning & 15 & 42,82 & 18,56 \\
& 20 & 55,90 & \\
\hline & 25 & 64,14 & \\
Vit.C & 1 & 8,04 & \\
& 2 & 20,58 & \\
& 3 & 41,05 & 3,63 \\
& 4 & 54,32 & \\
\hline
\end{tabular}

Berdasarkan Tabel 2, menunjukkan bahwa ekstrak etanol 96\% daun kemuning memiliki aktivitas antioksidan yang sangat kuat yaitu kurang dari $50 \mathrm{bpj}$. Pelarut yang digunakan adalah etanol $96 \%$ sehingga senyawa yang diduga memiliki aktivitas seperti flavonoid, tanin dan saponin tersari lebih banyak dan membantu memberikan aktivitas antioksidan.

\section{Hasil Uji Toksisitas}

Metode BSLT merupakan metode yang cepat, mudah dan memiliki tingkat kepercayaan yang tinggi. Dalam metode BSLT, tingkat toksisitas senyawa dinyatakan dengan nilai $\mathrm{LC}_{50}$ yaitu konsentrasi senyawa yang memberikan tingkat mortalitas sebesar $50 \%$ terhadap larva udang Artemia salina Leach. Pada saat penetasan telur setelah 24 jam, nauplii dipindahkan ketempat lain, karena agar Artemia salina Leach yang digunakan memiliki umur yang seragam. Dalam pengerjaannya ekstrak harus kering, agar larva yang mati bukan disebabkan oleh senyawa lain tetapi oleh senyawa metabolit sekunder. Senyawa yang bersifat bioaktif akan menyebabkan kematian larva udang yang tinggi, semakin kecil nilai $\mathrm{LC}_{50}$ akan semakin besar toksisitasnya. Ekstrak dapat dikatakan toksik terhadap larva udang jika memiliki nilai $\mathrm{LC}_{50}<1000 \mu \mathrm{g} / \mathrm{mL}$. Hasil pengujian toksisitas ekstrak daun kemuning dapat dilihat pada Tabel 3.

Tabel 3. Hasil Uji Toksisitas Ekstrak Daun Kemuning

\begin{tabular}{lccc}
\hline \multicolumn{1}{c}{ Sampel } & $\begin{array}{c}\text { Konsentrasi } \\
(\mathbf{b p j})\end{array}$ & $\begin{array}{c}\text { Kematian } \\
(\%)\end{array}$ & $\begin{array}{l}\mathbf{L C}_{50} \\
(\mu \mathbf{g} / \mathbf{m L})\end{array}$ \\
\hline Ekstrak & 20 & 20 & 149,52 \\
daun kemuning & 40 & 30 & \\
& 100 & 43,33 & \\
& 200 & 56,67 & \\
& 400 & 63,33 & \\
\hline
\end{tabular}




\section{Hasil uji antikolesterol}

Aktivitas ekstrak daun kemuning dalam menurunkan kadar kolesteol diduga disebabkan oleh adanya kandungan senyawa metabolit sekunder seperti flavonoid, tanin dan saponin. Gugus hidroksil pada kolesterol bereaksi dengan gugus keton pada flavonoid membentuk hemiasetal. Gugus karbonil pada flavonoid akan bereaksi dengan gugus hidroksil pada kolesterol dan membentuk ikatan hidrogen. Menurut penelitian saponin merupakan senyawa yang memiliki surfaktan yang berikatan dengan kolesterol dan empedu sehingga menurunkan absorsi kolesterol dalam tubuh (11). Hasil uji aktivitas antikolesterol dapat dilihat pada Tabel 4.

Tabel 4. Hasil Uji Aktivitas Antikolesterol Ekstrak Daun Kemuning

\begin{tabular}{lccc}
\hline \multicolumn{1}{c}{ Sampel } & $\begin{array}{c}\text { Konsentrasi } \\
(\mathbf{b} \mathbf{p})\end{array}$ & Inhibisi(\%) & $\begin{array}{c}\mathbf{I C}_{50} \\
(\boldsymbol{\mu} \mathbf{g} / \mathbf{m L})\end{array}$ \\
\hline Ekstrak & 400 & 25,10 & \\
daun kemuning & 500 & 40,09 & 593,95 \\
& 600 & 42,73 & \\
& 700 & 69,90 & \\
& 800 & 76,14 & \\
\hline
\end{tabular}

\section{Kesimpulan}

Hasil skrining fitokimia dari simplisia dan ekstrak daun kemuning mengandung saponin, flavonoid, tanin, kumarin, steroid dan triterpenoid, dan minyak atsiri.

Toksisitas BSLT pada ekstrak etanol 96\% daun kemuning memberikan nilai $\mathrm{LC}_{50}$ sebesar $149,52 \mu \mathrm{g} / \mathrm{mL}$ yang menunjukkan ekstrak daun kemuning bersifat toksik. Aktivitas antioksidan ekstrak etanol daun kemuning dengan metode DPPH menunjukkan aktivitas dengan kategori sangat kuat dengan nilai $I_{50}$ sebesar 18,56 $\mu \mathrm{g} / \mathrm{mL}$. Ekstrak daun kemuning diduga memiliki aktivitas sebagai antikolesterol yaitu dengan nilai $\mathrm{IC}_{50}$ sebesar $593,95 \mu \mathrm{g} / \mathrm{mL}$. Berdasarkan hasil penelitian menunjukkan bahwa daun kemuning mempunyai aktivitas antioksidan yang sangat kuat dan dapat dimanfaatkan sebagai obat herbal.

\section{Daftar Pustaka}

1. Farag RS, Abdel-Latif MS, Abd El Baky HH, Tawfeek LS. Phytochemical screening and antioxidant activity of some medicinal plants' crude juices. Biotechnology Reports. 2020 1;28

2. Deli Silvia, Kezia Katharina, Stefanny Agness Hartono. Pengumpulan Data Base Sumber Antioksidan Alami Berbasis Pangan Lokal di Indonesia. Surya Octagon Interdisciplinary Journal of Technology, 2016, 181- 198 
3. Anggunan. Pengaruh Infusa Daun Kemuning (Muraya paniculata(L)Jack) Terhadap Kadar Kolesterol Darah Tikus Putih (Rattus norvegicus) Wistar jantan. Jurnal Kedokteran Dan Kesehatan, 2014. 1(1): 24-32

4. Retno Gitawati, Lucie Widowati, Frans Suharyantodaun. Penggunaan Jamu pada Pasien Hiperlipidemia Berdasarkan Data Rekam Medik, di Beberapa Fasilitas Pelayanan Kesehatan di Indonesia. Jurnal Kefarmasian Indonesia. 2015.5 (1);4148

5. Taufika R, Sandra Arifin, Maya Melati. Produksi flavonoid daun kemuning (Murraya paniculata L. Jack) pada dosis pupuk organic dan interval panen yang berbeda. Bogor: Departemen Agronomi dan Hortikultura Fakultas Pertanian Institut Pertanian Bogor. 2016. h. 28.

6. Bustanussalam, Titi Parwati, Partomuan Simanjuntak. Isolasi, Elusidasi Struktrur dan Uji Bioaktivitas dari akar kemuning (Murraya exotica L). Jurnal Ilmu Kefarmasian Indonesia. 2014. .2(2). 63-70

7. Farnsworth NR. Biological and phytochemical screening of plants. Journal of Pharmaceutical Sciences. 1966; 55(3): 225-276.

8. Zhu CH, Lei Z, Luo Y. Studies on antioxidant activities of methanol extract from Murraya paniculata. Scientdirect2015; 4(3): 108-114.

9. Zuraida. Toxicity Analysis of Forestry Plants Using Brine Shrimp Lethality Test (BSLT) Method.Jurnal penelitian hasil hutan. 2018.36(3).239-246

10. R. Nalole, M. N. Djide, E. Wahyudin, A. I. Makhmud, Uji In Vitro Penurunan Kadar Kolesterol oleh Sari Kedelai Hitam (Glycine max Merr), Majalah Farmasi dan Farmakologi, 13, 1, (2019) 17-20

11. Feng, D., Ohlsson, L. and Duan, R.D., 2010, Curcumin Inhibits Cholesterol Uptake in Caco-2 Cells by Down-Regulation of NPC1L1 Expression, Lipid in Health and Disease, 9 (40), 